\title{
Pelaksanaan Kurikulum 2013 pada Bidang Studi Matematika di Sekolah Menengah Pertama Negeri (SMPN) Kota Pekanbaru Tahun Pelajaran 2016/2017
}

\author{
${ }^{1}$ Susda Heleni \\ 2Zulkarnain \\ 1,2 Program Studi Pendidikan Matematika FKIP Universitas Riau \\ Kampus Bina Widya KM 12,5 Simpang Baru, Pekanbaru 28293, Indonesia \\ E-mail:1ewisusda@yahoo.com
}

\begin{abstract}
This study aims to (1) Determine the implementation of curriculum 2013 in Mathematics on SMPN of Pekanbaru, the academic year 2016/2017. (2) Knowing what obstacles faced by Mathematics teachers SMPN of Pekanbaru in the implementation of kurikulm 2013. This study is a qualitative descriptive study, which describes the implementation of the curriculum 2013 by Mathematics teachers of SMPN Pekanbaru and the constraints they face. Subjects in this study are Mathematics teachers in SMPN Pekanbaru that implementing the curriculum 2013, such as SMP 1, SMP 6 and SMP 23 Pekanbaru. The data collection by conducting surveillance documents, and interviews with Mathematics teachers. Based on data analysis, learning process based curriculum 2013 in Pekanbaru SMP has not gone well. There are some problems in the implementation of the curriculum 2013 at SMPN Pekanbaru such as, (1) Teacher have a problem to making Student Activity Sheet; (2) Lack of teacher knowledge about models, strategies, or approach about student-centered learning; and (3) Lack of understanding about the assessment of teachers especially skills assessment.
\end{abstract}

Keywords: Curriculum 2013, Mathematics, SMPN.

\begin{abstract}
Abstrak
Penelitian ini bertujuan untuk (1) Mengetahui pelaksanaan kurikulum 2013 SMPN kota Pekanbaru pada bidang studi Matematika tahun pelajaran 2016/2017. (2) Mengetahui apa saja kendala yang dihadapi guru-guru Matematika SMPN kota Pekanbaru pada bidang studi Matematika tahun pelajaran 2016/2017 dalam pelaksanaan kurikulm 2013. Penelitian ini adalah penelitian deskriptif kualitatif, yang menggambarkan pelaksanaan kurikulum 2013 oleh guru-guru Matematika SMPN kota Pekanbaru dan kendala-kendala yang mereka hadapi. Subjek pada penelitian ini adalah guru-guru matematika di SMPN kota Pekanbaru yang melaksanakan kurikulum 2013 yaitu SMPN 1, SMPN 6 dan SMPN 23 kota Pekanbaru. Pengumpulan data dilakukan dengan mengadakan pengamatan dokumen, pembelajaran dan wawancara dengan guru matematika. Berdasarkan analisis data diperoleh bahwa pembelajaran yang dilakukan guru bidang studi matematika berdasarkan kurikulum 2013 di SMPN Pekanbaru belum berjalan dengan baik. Terdapat beberapa kendala dalam pelaksanaan kurikulum 2013 di SMPN Pekanbaru seperti, (1) guru kesulitan membuat Lembar Aktifitas Siswa; (2) kurangnya pengetahuan guru tentang model-model, strategi, atau pendekatan pembelajaran yang berpusat pada siswa; serta (3) kurangnya pemahaman guru tentang penilaian terutama penilaian keterampilan.
\end{abstract}

Kata Kunci: Kurikulum 2013, Bidang Studi Matematika, SMPN. 


\section{Pendahuluan}

Proses pembelajaran di kelas berkaitan erat dengan kompetensi guru, siswa, kurikulum serta sarana dan prasarana pendukungnya. Guru merupakan figur yang sangat krusial dalam proses pembelajaran di kelas, gurulah yang menentukan model, strategi, serta metode pembelajaran yang akan digunakan didalam kelas. Guru merupakan pekerjaan yang memerlukan keahlian khusus ${ }^{1}$. Tugas guru meliputi mendidik, mengajar, dan melatih. Mendidik berarti meneruskan dan mengembangkan nilai-nilai hidup. Mengajar berarti meneruskan dan mengembangkan ilmu pengetahuan dan teknologi. Sedangkan melatih berarti mengembangkan keterampilanketerampilan pada siswa.

Pemerintah melalui Departemen Pendidikan dan Kebudayaan melakukan pembaharuan dan inovasi dalam bidang pendidikan, salah satunya adalah pembaharuan dan inovasi kurikulum, yakni lahirnya kurikulum $2013{ }^{2}$. Lebih lanjut Kunandar mengatakan bahwa Kurikulum 2013 dikembangkan dengan penyempurnaan pola pikir sebagai berikut : (1) pola pembelajaran yang berpusat pada guru menjadi pembelajaran berpusat pada peserta didik. Peserta didik harus memiliki pilihan-pilihan terhadap materi yang dipelajari untuk memiliki kompetensi yang sama; (2) pola pembelajaran satu arah (interaksi guru-peserta didik) menjadi pembelajaran interaktif (interaktif guru-peserta didik-masyarakat-lingkungan alam, sumber/media lainnya); (3) pola pembelajaran terisolasi menjadi pembelajaran secara jejaring (peserta didik dapat menimba ilmu dari siapa saja dan dari mana saja yang dapat dihubungi serta diperoleh melalui internet); (4) pola pembelajaran pasif menjadi pembelajaran aktif; (5) pola belajar sendiri menjadi belajar kelompok (berbasis tim); (6) pola pembelajaran alat tunggal menjadi pembelajaran berbasis alat multimedia; (7) pola pembelajaran berbasis missal menjadi kebutuhan pelanggan (users) dengan memperkuan potensi khusus yang dimiliki setiap peserta didik ; (8) pola pembelajaran ilmu pengetahuan tunggal (monodiscipline) menjadi pembelajaran ilmu pengetahuan jamak (multidisciplines); dan (9) pola pembelajaran pasif menjadi pembelajaran kritis.

\footnotetext{
${ }^{1}$ Uzer Usman, Menjadi Guru Profesional (Bandung: Remaja Rosdakarya, 2011).

2 Kunandar, Penilaian Autentik (Penilaian Hasil Belajar Peserta Didik Berdasarkan Kurikum 2013) (Jakarta: PT Raja Grafindo Persada, 2014).
} 
Sementara itu menurut Widyastono, salah satu perubahan dalam kurikulum 2013 adalah adanya tambahan jam belajar ini dan pengurangan jumlah Kompetensi Dasar ${ }^{3}$. Rasional perubahan ini menurut beliau adalah terjadinya perubahan proses pembelajaran, dimana pada kurikulum 2006 siswa diberitahu berubah menjadi siswa mencari tahu dalam pembelajaran. Proses penilaian juga terjadi perubahan, yaitu dari penilaian berbasis output pada kurikulum 2006 menjadi penilaian berbasis proses dan output dalam kurikulum 2013. Dengan adanya tambahan jam belajar ini dan pengurangan jumlah Kompetensi Dasar, guru memiliki keleluasaan waktu untuk mengembangkan proses pembelajaran yang berorientasi siswa aktif belajar.

Proses pembelajaran siswa aktif memerlukan waktu yang lebih panjang dari proses pembelajaran penyampaian informasi karena peserta didik perlu latihan untuk melakukan pengamatan, menanya, asosiasi, dan komunikasi. Proses pembelajaran yang dikembangkan guru menghendaki kesabaran dalam menunggu respon peserta didik karena mereka belum terbiasa. Selain itu bertambahnya jam belajar memungkinkan guru melakukan penilaian proses dan hasil belajar. Sehingga perubahan tersebut di atas harus disosialisasikan secara luas pada semua pihak yang berkepentingan secara langsung dengan pendidikan di sekolah maupun pihak lain yang berkepentingan.

Implementasi Kurikulum 2013 merupakan langkah yang berkesinambungan dari kurikulum sebelumnya yaitu Kurikulum Berbasis Kompetensi dan Kurikulum Tingkat Satuan Pendidikan. Penyempurnaan kurikulum sebagai langkah untuk mencapai Tujuan Pendidikan Nasional. Perubahan kurikulum dilakukan sebagai salah satu langkah mengatasi berbagai persoalan kualitas moral bangsa, kualitas sumber daya manusia, dan tantangan perkembangan Ilmu Pengetahuan dan Teknologi.

Pelaksanaan Kurikulum 2013 menuntut kemampuan guru dalam penguasaan konsep esensial dan kemampuan pedagogi guru. Kurikulum 2013 menekankan pada domain sikap (spiritual, sosial), domain pengetahuan dan domain keterampilan. Keempat aspek ini selanjutnya akan menjadi dasar untuk penyusunan Kompetensi Inti (KI) dan penjabarannya menjadi Kompetensi Dasar (KD). Dalam kurikulum 2013, panduan pembelajaran dan buku ajar sudah ditetapkan dari pusat. Namun demikian guru dituntut untuk tetap dapat mengemas pembelajaran yang berorientasi pada aspek sikap, pengetahuan dan keterampilan.

3 Herry Widyastono, 'Kebijakan Pengembangan Kurikulum 2013', Sosialisasi Kurikulum 2013 Di Universitas Riau, November 2013.

Al-Khwarizmi - 45 
Pelaksanaan kurikulum 2013 merupakan sesuatu yang baru bagi guru, tak terkecuali guru Matematika. Secara umum, guru Matematika harus mempunyai empat kompetensi yaitu kompetensi pedagogi, professional, kepribadian dan sosial. Pada awal diluncurkannya kebijakan dan mulainya implementasi kurikulum 2013 telah menuai berbagai kontroversi. Menurut Alawiyah (2014) penyiapan kurikulum 2013 dinilai terlalu terburu-buru dan tidak mengacu pada hasil kajian yang sudah matang berdasarkan hasil evaluasi KTSP, dan kurang memperhatikan kesiapan satuan pendidikan dan guru. Padahal kurikulum ini mencakup beberapa perubahan penting baik dari sisi substansi, implementasi, sampai evaluasi. Meskipun demikian, kurikulum 2013 tetap dilaksanakan secara bertahap mulai tahun pelajaran 2013/2014. Pada Tahun Ajaran 2013/2014, Kurikulum 2013 dilaksanakan secara terbatas untuk Kelas I dan IV SD/MI, Kelas VII SMP/MTs, dan Kelas X SMA/ SMK/MA/MAK.

Tahun pelajaran baru 2014/2015 yang dimulai pada bulan Juli 2014 dan satuan pendidikan secara serentak mulai mengimplementasikan kurikulum 2013 yang merupakan perbaikan dari KTSP. Sejumlah kendala yang dapat ditemui dalam pelaksanaannya, antara lain terkait dengan anggaran, kesiapan pemerintah dalam menyiapkan perangkat kurikulum, kesiapan guru, sosialisasi, dan distribusi buku. Diantara semua daftar di atas, masalah utama yang sangat menghambat adalah kesiapan guru sebagai kunci keberhasilan implementasi kurikulum ini ${ }^{4}$.

Fakta terbaru tentang pelaksanaan kurikulum 2013 adalah pada semester genap 2014/2015, sekolah-sekolah yang baru melaksanakan kurikulum 2013 satu semester diberikan pilihan antara melanjutkan pelaksanaan kurikulum 2013 atau kembali pada kurikulum 2006 (Pernyataan Mendikbud RI). Kondisi ini menggambarkan ketidaksiapan pemerintah dalam hal ini Kemendikbud RI melaksanakan kurikulum 2013. Menurut Alawiyah, Pemerintah belum mampu melatih semua guru 5. Masih banyak guru yang telah diberikan pelatihan belum memahami dalam mengimplementasikan kurikulum 2013. Hal ini dikarenakan beberapa kekurangan dalam proses pelatihan antara lain dari sisi waktu pelatihan yang terlalu singkat, metode pelatihannya yang lebih banyak difokuskan pada ceramah, teori, dan kompetensi instruktur itu sendiri. Padahal, proses penyiapan guru melalui pelatihan harus ditekankan pada perbaikan kualitas guru, dan hal ini harus ditunjang dengan pelatihan yang berkualitas pula. Hal

4 Faridah Alawiyah, 'Kesiapan Guru Dalam Implementasi Kurikulum 2013', Info Singkat Kesejahteraan SosialVII, no. 15/I/P3DI/Agustus/2014 (2014).

${ }^{5}$ Ibid. 
ini yang harus terus ditingkatkan sehingga pelatihan bukan hanya sekedar formalitas kegiatan.

Kurikulum 2013 membawa perubahan mendasar peran guru dalam pembelajaran. Secara administratif, pemerintah pusat telah menyiapkan perangkat pelaksanaan pembelajaran yang tidak perlu lagi disiapkan oleh guru. Namun demikian, guru dituntut berperan secara aktif sebagai motivator dan fasilitator pembelajaran sehingga siswa akan menjadi pusat belajar. Menurut Alawiyah bukan persoalan yang mudah untuk mempersiapkan guru yang ideal seperti harapan kurikulum 2013 dalam waktu singkat, terutama untuk merubah mindset guru dari yang asalnya hanya bertugas untuk mengajar sementara dalam kurikulum 2013 guru harus mampu mengarahkan siswa untuk aktif, produktif ${ }^{6}$. Hal ini menjadi kendala tersendiri bagi para guru karena tidak semua guru memiliki kompetensi tersebut. Selain itu, guru dituntut kesiapannya untuk melaksanakan kurikulum dalam waktu yang relatif singkat sementara perangkatnya belum disiapkan secara matang.

Kenyataan lain yang peneliti jumpai untuk menghadapi pelaksanaan kurikulum 2013 (wawancara penulis dengan para guru peserta PLPG tahun 2015 Rayon 05 Universitas Riau) guru SMP/M.Ts di Riau merasa kesulitan dalam menyusun perangkat pembelajaran (RPP dan penilaian) berdasarkan kurikulum 2013. Hal ini disebabkan karena mereka belum memahami dengan baik tentang kurikulum 2013. Dari pengakuan guru tersebut banyak hal-hal yang belum dipahami dari kurikulum 2013 tersebut, namun mereka harus melaksanakan kurikulum 2013 dengan segala keterbatasannya .

Dalam penelitian ini, penulis akan melihat pelaksanaan kurikulum 2013 pada bidang studi Matematika di SMP dan akan menginfentarisir permasalahan-permasalahan yang dihadapi guru-guru Matematika SMP dalam pelaksanaan kurikulum 2013 sehingga dapat dicarikan solusi untuk guru-guru SMP dalam pembelajarannya.

\section{Metode Penelitian}

Penelitian ini dilaksanakan di SMPN kota Pekanbaru tahun pelajaran 2016/2017. Penelitian dilakukan pada semester ganjil tahun pelajaran 2016/2017. Bentuk penelitian ini adalah penelitian deskriptif kualitatif. Menurut Sanjaya, penelitian deskriptif kualitatif adalah metode penelitian yang bertujuan untuk menggambarkan secara utuh dan mendalam tentang realitas sosial dan berbagai fenomena yang terjadi di masyarakat yang menjadi subjek penelitian sehingga tergambarkan ciri-ciri, karakter, sifat,

\footnotetext{
${ }^{6}$ Ibid.
} 
dan model dari fenomena tersebut 7. Dalam penelitian ini, peneliti akan menggambarkan pelaksanaan kurikulum 2013 oleh guru-guru bidang studi Matematika SMPN kota Pekanbaru dan kendala-kendala yang mereka hadapi.

Subjek pada penelitian ini adalah guru-guru bidang studi Matematika dari tiga SMPN kota Pekanbaru yang melaksanakan kurikulum 2013. Informasi yang diperoleh dari Dinas Pendidikan kota Pekanbaru bahwa hanya ada SMPN kota Pekanbaru yang menggunakan kurikulum 2013 pada tahun ajaran 2016/2017, yaitu SMPN 1, SMPN 6, dan SMPN 23 kota Pekanbaru. Sehingga ketiga sekolah tersebut langsung diambil menjadi sampel dalam penelitian ini.

Instrumen utama dalam penelitian ini adalah peneliti sendiri, dalam arti peneliti sangat berperan dalam mengumpulkan data dan melakukan analisis. Ada beberapa alasan mengapa peneliti berperan sebagai instrumen utama dalam penelitian ini, diantaranya proses pemberian makna terhadap data verbal yang dijaring dengan wawancara dan pengamatan terhadap pelaksanaan pembelajaran berdasarkan kurikulum 2013 hanya dapat dilakukan oleh peneliti.

Pengumpulan data adalah prosedur yang sistematik dan standar untuk memperoleh data yang diperlukan. Pengumpulan data tidak lain dari suatu proses pengadaan data primer untuk keperluan penelitian. Secara umum metode pengumpulan data dapat dibagi atas tiga kelompok, iaitu: 1) metode pengamatan; 2) metode dengan menggunakan pertanyaan (wawancara); 3) metode khusus ${ }^{8}$. Dalam penelitian ini pengumpulan data menggunakan metode pengamatan dan metode menggunakan pertanyaan (wawancara).

Data mentah yang telah dikumpulkan peneliti tidak akan berguna jika tidak dianalisis. Analisis data dapat memberi arti dan makna yang berguna dalam memecahkan masalah penelitian. Analisis data adalah suatu kegiatan yang berupaya mencermati apakah persiapan proses dan hasil pekerjaan sudah sesuai dengan tujuan yang ingin dicapai. Menurut Moleong, proses analisis data dimulai dengan menelaah seluruh data yang tersedia dari berbagai sumber' .

7 Wina Sanjaya, Strategi Pembelajaran Berorientasi Standar Proses Pendidikan (Jakarta: Kencana, 2013).

8 Zulkarnain, 'Pengajaran Dan Pembelajaran Matematik Melalui Soalan Berayat Berbentuk Kontekstual: Penyelidikan Tindakan Di Sdn 004 Rumbai Pekanbaru' (Fakulti Pendidikan UKM, 2011).

${ }^{9}$ Lexy J Moleong, Metodologi Penelitian Kualitatif (Bandung: PT. Remaja Rosdakarya Offset, 2006). 
Data pengamatan merupakan data kualitatif sehingga dianalisis dengan analisis kualitatif. Menurut Bogdan \& Biklen, analisis data kualitatif adalah upaya yang dilakukan dengan jalan bekerja dengan data, mengorganisasikan data, memisah-misahnya menjadi satuan yang dapat dikelola, mensintesiskannya, mencari dan menemukan pola, menemukan apa yang penting, dan memutuskan apa yang dapat dideskripsikan pada orang lain ${ }^{10}$.

Dalam penelitian ini, peneliti mengamati dengan menggunakan lembar pengamatan yang sudah dikategorikan, sehingga data yang diperoleh dengan lembar pengamatan tersebut sudah terpisah sesuai dengan kategorinya. Peneliti juga menggunakan catatan lapangan untuk mencatat peristiwa yang tidak termasuk dalam kategori yang dipersiapkan dalam lembar pengamatan.

Menurut Moleong, wawancara adalah percakapan dengan maksud tertentu. Menurut beliau data hasil temubual berupa data kualitatif 11. Data hasil wawancara merupakan data yang cukup kompleks dan menurut Miles dan Huberman, data yang kompleks ini dianalisis dengan teknik analisis kualitatif, yang salah satu modelnya adalah teknik interaktif 12 . Analisis interaktif tersebut terdiri atas tiga komponen kegiatan yang terkait satu sama lainnya, yaitu: (i) reduksi data, (ii) pemaparan data, dan (iii) penarikan kesimpulan

Reduksi data merupakan proses menyeleksi, menentukan fokus, menyederhanakan, dan meringkas. Dalam proses ini dilakukan penajaman, pemilahan, pemfokusan, penyisihan data yang kurang bermakna, dan menyusunnya sehingga kesimpulan dapat diambil dan dapat diverifikasi. Dalam penelitian ini, pada tahap reduksi peneliti membuat transkripsi wawancara secara manual dan dibantu dengan alat perekam. Transkripsi tersebut adalah sebagai dasar penganalisian data wawancara.

Setelah data direduksi, data siap dipaparkan. Dalam penelitian ini berbagai tema dan subtema data wawancara yang telah direduksi dipaparkan dalam bentuk narasi. Pemaparan data yang baik akan memudahkan pemahaman terhadap apa yang terjadi sehingga memudahkan penarikan kesimpulan.

10 Robert Bogdan and Sari Knopp Biklen, Qualitative Reaserch for Education an Introduction to Theory and Methods, 3rd ed. (Boston: Allyn and Bacon, 1998).

11 Moleong, Metodologi Penelitian Kualitatif.

12 Zulkarnain, 'Pengajaran Dan Pembelajaran Matematik Melalui Soalan Berayat Berbentuk Kontekstual: Penyelidikan Tindakan Di Sdn 004 Rumbai Pekanbaru'.

Al-Khwarizmi - 49 


\section{Pelaksanaan Kurikulum 2013}

\section{Hasil Pengamatan tentang Perencanaan Pembelajaran}

Hasil pengamatan dan wawancara tentang perencanaan pembelajaran yakni silabus, Rencana Pelaksanaan Pembelajaran (RPP), penilaian, Lembar Aktifitas Siswa (LAS), dan pelaksanaan pembelajaran di kelas serta kendalakendala pelaksanaan kurikulum Kurikulum 2013 diuraikan sebagai berikut:

1. Silabus

Hasil pengamatan dokumen silabus yang digunakan guru-guru Matematika SMPN kota Pekanbaru diperoleh bahwa ada dua bentuk silabus yang digunakan, yaitu (1) silabus yang diterbitkan oleh Kemendikbud tahun 2013 yang sesuai dengan Permendikbud nomor 22 tahun 2016. (2) Silabus yang diberikan nara sumber nasional pada saat guru-guru Matematika mengikuti pelatihan pelaksanaan kurikulum 2013 yang hanya terdiri dari tiga kolom dan silabus ini tidak sesuai dengan komponen yang ada pada Permendikbud nomor 22 tahun 2016.

2. Rencana Pelaksanaan Pembelajaran (RPP)

Guru-guru Matematika SMPN kota Pekanbaru sudah membuat RPP sesuai dengan format Permendikbud nomor 22 tahun 2016. RPP yang dibuat gurupun sudah mencantumkan pelaksanaan pembelajaran dengan pendekatan saintifik dan model pembelajaran yang dianjurkan oleh Permendikbud nomor 22 tahun 2016. Namun RPP yang dibuat bukan berdasarkan silabus yang sudah dikemas dengan baik.

3. Lembar Aktifitas Siswa (LAS)

LAS merupakan pusat kegiatan pembelajaran pada kurikulum 2013 atau dapat dikatakan merupakan rohnya kurikulum 2013. Namun dari hasil pengamatan dokumen dan pelaksanaan pembelajaran guru tidak mempunyai LAS yang dibuat oleh guru sendiri yang sesuai dengan kerakteristik pembelajaran kurikulum 2013, yaitu siswa mencari tahu, menemukan konsep, dan rumus dari materi yang dipelajari. Kalaupun ada lembar kerja yang digunakan adalah lembar kerja yang berisikan ringkasan materi dan kumpulan soal yang tidak sesuai dengan prinsip pembelajaran kurikulum 2013.

4. Penilaian

perancangan strategi penilaian oleh guru dilakukan pada saat penyusunan rencana pelaksanaan pembelajaran (RPP) berdasarkan silabus. Penilaian hasil belajar siswa pada pendidikan dasar dan pendidikan menengah meliputi aspek: (1) Sikap; (2) Pengetahuan; dan (3) Keterampilan. Penilaian aspek sikap dilakukan melalui observasi/pengamatan dan teknik penilaian lain yang relevan, dan 
pelaporannya menjadi tanggungjawab wali kelas atau guru kelas (Permendikbud nomor 23 tahun 2016). Selanjutnya, menurut Permendikbud tersebut, penilaian yang menjadi tanggung jawab guru mata pelajaran Matematika di SMP adalah penilaian pengetahuan dan keterampilan. Hasil pengamatan terhadap RPP yang dibuat guru yang di dalamnya ada format penilaian diperoleh bahwa guru telah membuat format penilaian pengetahuan, namun belum mencantumkan format penilaian keterampilan.

5. Pelaksanaan Pembelajaran di Kelas

Proses Pembelajaran pada satuan pendidikan diselenggarakan secara interaktif, inspiratif, menyenangkan, menantang dan memotivasi siswa untuk berpartisipasi aktif dalam pembelajaran (Permendikbud nomor 22 tahun 2016). Pola pembelajaran yang diharapkan dalam kurikulum 2013 adalah pola pembelajaran berpusat pada guru menjadi pembelajaran berpusat pada peserta didik (Permendikbud nomor 69 tahun 2013). Hasil pengamatan pelaksanaan pembelajaran di dalam kelas diperoleh bahwa pelaksanaan pembelajaran masih berpusat pada guru. Guru masih mendominasi pelaksanaan pembelajaran. Metode pembelajaran yang digunakan adalah dominan menggunakan metode ekspositori yang berpusat pada guru.

6. Kendala-Kendala Pelaksanaan Kurikulum 2013 di SMP

Hasil wawancara dengan guru matematika di sekolah sampel diperoleh bahwa guru matematika mengalami kesulitan dalam melaksanakan kurikulum 2013 disebabkan beberapa hal sebagai berikut: 1) guru kesulitan membuat Lembar Aktifitas Siswa; 2) kurangnya pengetahuan guru tentang model-model, strategi, atau pendekatan pembelajaran yang berpusat pada siswa; serta 3) kurangnya pemahaman guru tentang penilaian terutama penilaian keterampilan.

\section{Pembahasan Hasil Pengamatan tentang Perencanaan Pembelajaran}

Silabus merupakan acuan penyusunan kerangka pembelajaran untuk setiap bahan kajian mata pelajaran. Silabus paling sedikit memuat: a). Identitas mata pelajaran; b). Identitas sekolah meliputi nama satuan pendidikan dan kelas; c). Kompetensi inti; d). Kompetensi dasar; e). Materi pokok; f). Pembelajaran; g). Penilaian; h). Alokasi waktu; dan i). Sumber belajar. Silabus dikembangkan berdasarkan Standar Kompetensi Lulusan dan Standar Isi untuk satuan pendidikan dasar dan menengah sesuai dengan pola pembelajaran pada setiap tahun ajaran tertentu. Silabus digunakan sebagai acuan dalam pengembangan rencana pelaksanaan pembelajaran (Permendikbud nomor 22 tahun 2016). Berdasarkan keterangan Permendikbud di atas, begitu lengkapnya silabus yang seharusnya dikemas 
oleh guru sehingga silabus benar-benar dapat berguna untuk acuan mengembangkan rencana pelaksanaan pembelajaran (RPP). Jika silabus sudah dikemas dengan baik, silabus juga bisa menjadi pedoman dalam membuat lembar aktifitas siswa (LAS). Namun dari hasil pengamatan silabus guru didapat bahwa guru hanya mengambil secara langsung silabus yang diterbitkan Kementerian Pendidikan Nasional tanpa mengemasnya menjadi silabus yang dapat dijadikan pedoman pembuatan RPP dan LAS. Bahkan silabus terakhir yang diperoleh guru matematika dari pelatihan kurikulum 2013, silabus yang diberikan hanya berisikan ruang lingkup materi yang akan diajarkan pada kelas VII, VIII, dan IX.

Rencana Pelaksanaan Pembelajaran (RPP) adalah rencana kegiatan pembelajaran tatap muka untuk satu pertemuan atau lebih. RPP dikembangkan dari silabus untuk mengarahkan kegiatan pembelajaran peserta didik dalam upaya mencapai Kompetensi Dasar (KD) (Permendikbud nomor 22 tahun 2016). Hasil pengamatan terhadap RPP yang dibuat guru sudah sesuai dengan format Permendikbud nomor 22 tahun 2016. RPP yang dibuat gurupun sudah mencantumkan pelaksanaan pembelajaran dengan pendekatan saintifik dan model pembelajaran yang dianjurkan oleh Permendikbud nomor 22 tahun 2016. Namun RPP yang dibuat guru bukan dikembangkan berdasarkan silabus yang sudah dikemas. Guru membuat RPP berdasarkan pengalaman mengajar materi pada tahun-tahun sebelumnya.

Pelaksanaan pembelajaran merupakan implementasi dari RPP, meliputi kegiatan pendahuluan, inti dan penutup. Prinsip pembelajaran yang digunakan dalam kurikulum 2013 adalah dari siswa diberi tahu menuju siswa mencari tahu (Permendikbud nomor 22 tahun 2016). Hal ini dapat terlaksana jika guru menggunakan LAS dalam pembelajaran. Namun yang terjadi adalah guru matematika tidak memiliki LAS yang dapat mengaktifkan siswa dalam pembelajaran. Sehingga dalam pembelajaran guru matematika umumnya masih dominan menggunakan metode ekspositori yang pembelajarannya berpusat pada guru.

Penilaian hasil belajar peserta didik pada pendidikan dasar dan pendidikan menengah meliputi aspek: a). sikap; b). pengetahuan; dan c). keterampilan. Penilaian sikap merupakan kegiatan yang dilakukan oleh pendidik untuk memperoleh informasi deskriptif mengenai perilaku peserta didik. Penilaian pengetahuan merupakan kegiatan yang dilakukan untuk mengukur penguasaan pengetahuan peserta didik. Penilaian keterampilan merupakan kegiatan yang dilakukan untuk mengukur kemampuan peserta didik menerapkan pengetahuan dalam melakukan tugas tertentu. Penilaian pengetahuan dan keterampilan dilakukan oleh pendidik (Permendikbud nomor 23 tahun 2016). Guru matematika sudah terbiasa melakukan penilaian pengetahuan, namun masih kesulitan dalam melakukan penilaian 
keterampilan. Guru matematika mengalami kesulitan dalam membuat pedoman penilaian keterampilan

\section{Penutup}

Berdasarkan analisis dan pembahasan penelitian diperoleh bahwa; (1). Pembelajaran yang dilakukan guru bidang studi matematika berdasarkan kurikulum 2013 di SMPN kota Pekanbaru belum berjalan dengan baik. (2). Terdapat beberapa kendala dalam pelaksanaan kurikulum 2013 di SMPN kota Pekanbaru seperti, 1) guru kesulitan membuat Lembar Aktifitas Siswa; 2) kurangnya pengetahuan guru tentang model-model, strategi, atau pendekatan pembelajaran yang berpusat pada siswa; serta 3) kurangnya pemahaman guru tentang penilaian terutama penilaian keterampilan.

Berdasarkan kesimpulan di atas, dapat disarankan; (1). Penambahan pemahaman guru tentang model-model, strategi atau pendekatan pembelajaran dan penilaian., (2). Mengingat pentingnya LAS dan kuantitas LAS yang akan dibuat cukup banyak dan kuantitas guru matematika SMPN kota Pekanbaru cukup banyak maka perlu mengaktifkan MGMP bidang studi matematika dalam membuat LAS., (3). Pendampingan dari tenaga ahli tentang pelaksanaan kurikulum 2013.

\section{Daftar Pustaka}

Alawiyah, Faridah. 'Kesiapan Guru Dalam Implementasi Kurikulum 2013'. Info Singkat Kesejahteraan Sosial VII, no. 15/I/P3DI/Agustus/2014 (2014).

Bogdan, Robert, and Sari Knopp Biklen. Qualitative Reaserch for Education an Introduction to Theory and Methods. 3rd ed. Boston: Allyn and Bacon, 1998.

Kunandar. Penilaian Autentik (Penilaian Hasil Belajar Peserta Didik Berdasarkan Kurikum 2013). Jakarta: PT Raja Grafindo Persada, 2014.

Moleong, Lexy J. Metodologi Penelitian Kualitatif. Bandung: PT. Remaja Rosdakarya Offset, 2006.

Sanjaya, Wina. Strategi Pembelajaran Berorientasi Standar Proses Pendidikan. Jakarta: Kencana, 2013.

Usman, Uzer. Menjadi Guru Profesional. Bandung: Remaja Rosdakarya, 2011.

Widyastono, Herry. 'Kebijakan Pengembangan Kurikulum 2013'. Sosialisasi Kurikulum 2013 Di Universitas Riau, November 2013.

Zulkarnain. 'Pengajaran Dan Pembelajaran Matematik Melalui Soalan Berayat Berbentuk Kontekstual: Penyelidikan Tindakan Di Sdn 004 Rumbai Pekanbaru'. Fakulti Pendidikan UKM, 2011. 
